\title{
Examining the Use Self-perceived by University Teachers about ICT Resources: Measurement and Comparative Analysis in a One-way ANOVA Design
}

\author{
Francisco David Guillén-Gámez \\ Department of Research and Diagnostic Methods in Education, Faculty of Education, University of Zaragoza \\ (UNIZAR), Spain \\ ORCID: 0000-0001-6470-526X \\ Maria Jose Mayorga-Fernández \\ Department of Didactics and School Organization, Faculty of Sciences of Education, University of Málaga \\ (UMA), Spain \\ ORCID: 0000-0003-3749-1264 \\ Marta Ramos \\ Department of Developmental and Educational Psychology. University of Salamanca (USAL), Spain \\ ORCID: 0000-0002-9643-6495
}

Received: 3 Aug 2020

Accepted: 4 Sep 2020

\begin{abstract}
The growing rise of information and communication technologies (ICT) in all areas of society demands that university professors have an adequate level of digital literacy, so that they can contribute effectively to the training of their students and respond to the demands of the job. The objective of this research is to know and compare the use by university teachers of different ICT resources, in their teaching, evaluation, and research (UTIC-EEI model, its acronym in Spanish), depending on the area of knowledge to which they belong (science and engineering-architecture, health sciences, art-humanities, and sociallegal Sciences), in order to be able to take measures to effectively address the digital shortcomings of teachers. An ex post facto study is carried out, with a quantitative methodology utilising a survey technique, with a sample of 867 Spanish university teachers, with a descriptive and inferential analysis via ANOVA for multiple comparisons. The results showed a medium-high use by teachers of ICT resources in four areas, with there being a superior use in the teaching and research dimensions compared to the evaluation dimension in each area of knowledge. These data underline the need to continue training teachers to make excellent instrumental use of specific ICT resources in each area of knowledge.
\end{abstract}

Keywords: digital literacy, teachers, ICT, educational use, ANOVA

\section{INTRODUCTION}

The ongoing evolution in the Spanish educational field is unquestionably the result of the influence of new information and communication technologies (ICT) (Gorghiu, Gorghiu, \& Pascale, 2018), since they constitute a key component in the development of the teaching and learning process, thus promoting "great opportunities to improve the quality, accessibility and equity of education" (European Commission, 2012, p. 10). In this reality, higher education institutions whose purpose, according to the guidelines of the European Higher Education Area (EHEA), is to train professionally competent school-leavers to enter and be effective 
in the 21st century labour market (Fernández-Márquez, Leiva-Olivencia, \& López-Meneses, 2018). As affirmed by Carrera \& Coiduras (2012), the incorporation of ICT in higher education has led to changes in the teaching methods of university teachers, due to the emergence of both technological resources and learning management system (LMS). In this situation, teachers play an important role as change agents (Prendes, Gutiérrez, \& Martínez, 2018), while students represent the heart of the learning process (Adetimirin, 2019). Therefore, the success of the integration of ICTs in teaching and learning processes will largely depend on the teachers' skills to implement these technologies in an optimal way (Hernández, 2017; Lai, 2019), given that the use of technology in the teaching process can have a positive impact on students' learning (Bingimlas, 2009; DiVall et al., 2013; Karpudewan \& Balasundram, 2019). However, as indicated by López, Sánchez, Arámbula, and Esquivel (2019), such use of technology is taking place regarding the method, but is not causing fundamental transformations.

A challenge may arise in the case where teachers have not received sufficient digital training, through innovative teaching methodologies focused on pedagogical-technological issues in the context of higher education institutions, aimed to meet the demands emerging in their practice (Adetimirin, 2019; Cela-Ranilla et al., 2017), so highlighting they have on a low level of ICT skills (Arancibia, Valdivia, Araneda, \& Cabero, 2017; Dzikite, Nsubuga, \& Nkonki, 2017; Guillén-Gámez, Mayorga-Fernández, \& Del Moral, 2020a; Mercader, 2019; Ojeniyi \& Adetimirin, 2016; Prendes \& Castañeda, 2010). This limited training is partly attributable to the fact that training has focused on issues related to technical-instrumental management and not on integrating ICT into didactic-curricular practice (Llorente, 2008). Furthermore, Gutiérrez, Torres, and Sánchez-Beato (2016) analysed teaching guides of the study plans of three Spanish universities, and found that ICT were hardly present. Furthermore, Sahin and Thompson (2006) discovered that while technology is used in the field of administration and research, it is rarely used for teaching purposes because its inclusion poses challenges to the methods and mental abilities of the teaching staff. However, Díaz, Hernández, and Berea (2016), and Capilla, Torres, and Sánchez (2016) highlight that teachers do not dislike the didactic integration of ICT in their educational processes; on the contrary, they recognise its pedagogical potential. Arguably, the problem lies in "the laboriousness involved in the teaching planning of the different educational levels when employing specific digital resources to improve learning processes in each of the knowledge disciplines" (Carvalho, Tejada, \& Pérez, 2019, p. 73).

In the scientific literature, various authors (Guillén-Gámez, Mayorga-Fernández, Bravo-Agapito, \& EscribanoOrtiz, 2020b; Hatlevik \& Christophersen, 2013; Janssen et al., 2013) have sought to clarify the concept of digital literacy, a complex task, since there are multiple forms of understanding and naming it, among them: digital literacy, digital alphabetising, media literacy, digital skills, or internet skills. Digital literacy can be defined as the technological knowledge, practical use, and attitudes encouraging the critical, responsible, and creative use of ICT for different purposes (Padilla-Hernández \& Vanesa, 2018). In the education field and in line with this contribution, as well as with the findings of From (2017) and Rivera-Laylle, FernándezMorales, Guzmán-Games, and Eduardo-Pulido (2017), digital literacy is understood as a multifaceted and plural concept made up of three dimensions: (1) technological knowledge; (2) attitudes; and (3) didactic use; in three areas of application - teaching, evaluating, and researching - in order to provide students with optimal learning contexts (Carrera \& Coiduras, 2012; Pozos, 2016; Prendes et al., 2018). Specifically, this research aims to thoroughly investigate one of these dimensions of digital literacy in particular: its didactic use (Guillén-Gámez \& Mayorga-Fernández, 2019).

Various studies (Carrera \& Coiduras, 2012; Pozos, 2016) have highlighted the need for university teachers to develop didactic use of technology within their digital literacy, in a transversal manner, in each of the roles and duties they must perform within their knowledge area. In other words, they must develop this dimension of digital literacy both in teaching (the teaching-learning process) and research processes, in order to provide quality teaching on the one hand, and effective development of scientific knowledge on the other. Therefore, it is essential for teachers to use their digital skills to teach, evaluate, and research - combined, this can be referred to as the UTIC-EEI model (use of ICT to teach, evaluate, and research, for its acronym in Spanish). For this reason, in this research it has been decided to design a model called UTIC-EEI (use of ICT to teach, 
evaluate, and research, for its acronym in Spanish), where the digital competence of teachers is assessed in the most important professional fields of university teachers.

When carrying out a literature search on the studies previously carried out in regard to university teachers' level of competence by branch of knowledge, it can be seen that teachers who work in the experimental and technological fields have an adequate background in ICT, but not from the pedagogical and didactic point of view (Martínez \& González, 2015); that is, they make only an instrumental use of ICT. On the other hand, teachers who work in the human and social sciences field still use ICT in a traditional way to transmit information to their students, including through virtual classrooms, to plan their classes and even to evaluate their students (Lorenzo , 2018), considering their low level of technological knowledge (Ladrón-de-Guevara, Almagron, \& Cabero, 2019). Teachers in the education sciences field state that they fluently use communication tools, word processors, and online documentation, and report challenges when using online editing tools, online information management, collaborative online work, web 2.0 tools, and multimedia content creation (Carrera \& Coiduras, 2012; Pérez-Díaz, 2019).

After conducting a study of 117 teachers in the engineering faculties of the University of Bogotá, Martínez and González (2015) concluded that most teachers used ICT resources in their everyday life, most commonly email, followed by websites, forums, social networks, and chat platforms. In regard to their didactic use of technology, they employed word processors, created didactic material, for instance using PowerPoint, and spreadsheets for scores; on the other hand, they claimed not to know the potential of learning management system (LMS) for managing activities and resources. In relation to teachers who work in the health sciences field, De Ovando and Jara (2019) analysed the use of ICT by 94 university teachers at a private university in Chile, specifically, technological use, didactic use, and design of digital educational materials. The results showed that they had a high level of use with respect to the technological use dimension; a medium-high level in the didactic use dimension; and finally, a medium level in the design dimension of digital educational material. These results coincide with those found by Prendes and Gutiérrez (2013) on the didactic use dimension.

On the other hand, Fernández-Márquez et al. (2018) carried out a study focused on teachers of social and legal sciences, based on 53 teachers at the University of Malaga, and concluded that they had a basic level of digital use; moreover, according to the study, these teachers considered the integration of ICT in their teaching processes to be unnecessary. Despite this, they confirmed their extensive use of word processors, followed by multimedia presentations and search engines, along with their infrequent use of specific software and social networks. Furthermore, among the study's findings, the authors highlighted the main factors hindering the teachers' use of ICT, as follows: lack of training, lack of time, and the absence of technological devices. In the business and economic sciences field, Fernández, Sánchez-Oro, and Robina (2016), after conducting a study at the University of Extremadura with 84 teachers in this field, concluded that the importance given to digital literacy, in each of its dimensions, as well as the possibility of applying this skill in day-to-day life, was relatively low. Despite this, these teachers assigned great importance to its use when accessing information sources, but trivialised the use of web 2.0 and multimedia resources for teaching.

Therefore, it can be observed that teachers from experimental and technological fields make greater instrumental use of ICT. This highlights the necessity to develop a greater digital-pedagogical development in all fields, since its deficiency hampers the implementation and use of ICT in educational contexts (ColasBravo, De Pablos-Pons, \& Ballesta-Pagan, 2018; Ríos, Gómez, \& Rojas, 2018). However, it should be noted that most of the studies published to date have been carried out using an individualistic approach, without taking into account the UTIC-EEI model. In addition, most of these investigations have focused on teachers from a single branch of knowledge, with no studies which jointly analyse and compare the use of ICT resources by university teachers according to the areas of knowledge they are specialised in (sciences and engineering-architecture, health sciences, art-humanities, and social-legal sciences).

In view of the above, the present work will focus on analysing whether Spanish university teachers efficiently take advantage of the possibilities offered by ICT for both teaching and research competences, and whether 
any differences exist between teachers in this regard depending on their branch of knowledge. For this reason, the aim of this research is to know and compare the didactic use by university teachers of different ICT resources according to each branch of knowledge, so as to take measures to effectively address their digital deficiencies.

\section{METHOD}

\section{Design}

An ex post facto methodological design was used in this study, through surveys (Kerlinger, Lee, Pineda, \& Mora Magaña, 2002). The expression "ex post facto" means after the events have occurred, since the subjects are selected after the VI has occurred. It was decided to use this design since none of the variables have been modified in the development of the study. First, we present a descriptive analysis followed by an inferential analysis, in order to analyse and compare the university teachers' level of didactic use, by branch of knowledge, based on the UTIC-EEI model.

\section{Sample-population}

The population under study was composed of 120,383 higher education teachers from the Spanish Educational System (MECD, 2018-2019). On this population, non-probabilistic intentional sampling was carried out, with the sample selected according to the branches of knowledge mentioned previously. The sample consisted of a total of 12,538 teachers, who were contacted via email, respecting the confidentiality and privacy of data. In total 1,206 teachers responded. An exploratory analysis was later carried out to refine the database, resulting in a definitive sample of 867 university teachers since some of them did not fill out the complete survey. The distribution of the teaching staff according to the branches of knowledge was as follows: social-legal sciences $(N=400)$; sciences and engineering-architecture $(N=183)$; health sciences $(N=$ 173); and art-humanities ( $N=111)$. Regarding the intentional sampling, the intention was to collect a large sample of teachers from each area of knowledge. Furthermore, the authors tried to collect a large and similar sample in each of the areas so that the results were not influenced by the sample size. The only area in which the sample size was larger was Social Sciences since it is the area to which the authors belong, and consequently, we were more interested in analyzing.

\section{Instrument}

To measure the level of didactic use of ICT resources in university teachers, an instrument was designed utilizing a five-point Likert scale. Such level was measured in different web 2.0 tools classified in three dimensions which compose the UTIC-EEI model. Understood as web 2.0 tools those where the user becomes an active agent in the design and development of content and services through the network (Nafría, 2007). The first dimension was made up of five items related to the use of ICT resources in teaching tools; the second dimension was made up of four items focused on the use of ICT resources for student assessment; and the third dimension was made up of seven items related to the use of ICT resources for research. The instrument contained a total of 16 items. Regarding the level of educational use and the five-point Likert scale, a score obtained by teachers between 1 and 2 points was deemed to represent a low level of use; a score between 2 and 3 points represented a medium-low level; a score between 3 and 4 represented a medium level; and a score between 4 and 5 points represented a high level.

\section{Analysis of the Reliability and Validity of the Instrument}

The reliability of the instrument was guaranteed using Cronbach's $\alpha$. The total reliability of the instrument was $\alpha=0.90$, being a very acceptable value. Likewise, the reliability of each of the dimensions was also high: ICT resources for teaching, $\alpha=0.81$; ICT resources for evaluation, $\alpha=0.81$; ICT resources for research, $\alpha=$ 0.86 .

To determine the validity of the instrument, Exploratory Factor Analysis (EFA) was carried out using the maximum likelihood extraction, to observe the presence of correlation between items and factors. Construct 
validity was demonstrated, in the first instance, based on the value obtained in the Kaiser-Meyer-Olkin index $(\mathrm{KMO}=.913)$ and the Bartlett's test of sphericity with a chi-square score of $6317,040(p=.001)$, which indicated the factor analysis accuracy. The oblimin (oblique rotation) method was used since we consider that the factors are related, which revealed the presence of three factors and explained $59.81 \%$ of the true variance of the instrument. Subsequently, AMOS 22.0 software determined the goodness of fit of the proposed model through Confirmatory Factor Analysis (CFA), obtaining the following values: chi-square as test of contrast hypothesis (CMIN/DF, 3.890), considering that values less than 5 indicate a good fit (Bentler, 1989); the comparative fit index (CFI, 0.955) and the incremental fit index (IFI, 0.955), considering values above .900 to represent a good adjustment (Hu \& Bentler, 1999); and for the root mean square error of approximation (RMSEA, 0.058), where values below 0.06 indicate a good fit of the model.

\section{Procedure and Data Analysis}

The data analysis included several procedures, which are detailed below:

a) Second, a descriptive analysis was carried out on the level of didactic use according to the proposed model, which was classified according to the branches of knowledge.

b) Finally, multiple comparisons were carried out, in order to be able to infer if there were statistically significant differences in the level of use between the different branches of knowledge.

\section{ANALYSIS OF RESULTS}

\section{Descriptive Analysis of the Teachers' Use, based on the UTIC-EEI Model}

Table 1 shows the means of the items for each of the dimensions related to the UTIC-EEI instrument, according to the branch of knowledge the teaching staff belonged to. Regarding the use of ICT resources for the teaching dimension, it was generally observed that word processors and multimedia presentations were the most-used resources, with scores close to the maximum value of the five-point Likert scale, being slightly higher than the use of both these resources in the sciences and engineering-architecture branch ( $M=4.64$ word processors; $M=4.64$ multimedia presentations). It should be noted that the most-used ICT resources were learning management systems (LMS) and Google+ in all areas. Also, LMS use was slightly higher in engineering $(M=3.86)$ and Google+ in social sciences $(M=3.75)$. It was also observed that content platforms and educational forums were less used by teachers, with average levels in all branches of knowledge, and use of both resources being slightly lower in health sciences $(M=2.13$ content platforms: $M=2.42$ educational forums).

Regarding the use of ICT resources to evaluate students, it was observed that the most used resources were rubrics and test-type controls through LMS. Specifically in rubrics, it was observed that the sciences and engineering-architecture $(M=3.33)$ branch showed a slightly higher level of use, with a similar average for the social-legal sciences branch ( $M=3.32$ ); while the branch of teaching staff that made greatest use of testtype controls was sciences and engineering-architecture $(M=3.48)$. On the other hand, the use of eportfolios or forums to evaluate activities was less common than the use of the previously mentioned resources, showing a medium level of use, with the sciences and engineering-architecture branch making least use of these ICT resources ( $M=2.36$ e-portfolios; $M=2.68$ forums to evaluate activities).

Finally, the results for the use of ICT resources for research dimension showed that the most-used resource by teachers was the academic Google search engines for scientific consultations; the science and engineering-architecture branch obtained a slightly higher average compared to the other branches of knowledge ( $M=4.52$ ). The use of search engines in databases or impact journals showed similar values, with the teachers from the science and engineering-architecture branch demonstrating the highest use of these resources ( $M=4.29$ search engines and databases; $M=4.42 \mathrm{JCR}$ journal websites and SJR according to their quartiles). In regard to the use of programs for data analysis, the teachers claimed to have a medium-high level of use, being superior in the health sciences branch $(M=3.84)$ compared to, for example, the arthumanities branch $(M=2.74)$. 
Table 1. Didactic use for each dimension of the instrument and branch of knowledge

\begin{tabular}{|c|c|c|c|c|c|}
\hline & Items & $\begin{array}{l}\text { Sciences and } \\
\text { Engineering- } \\
\text { Architecture }\end{array}$ & Health Sciences & $\begin{array}{l}\text { Art- } \\
\text { Humanities }\end{array}$ & $\begin{array}{l}\text { Social-Legal } \\
\text { Sciences }\end{array}$ \\
\hline \multirow[t]{7}{*}{ Teach } & Word processors (Word, Open office, Docs) & $4.64 \pm 0.60$ & $4.59 \pm 0.64$ & $4.41 \pm 0.65$ & $4.49 \pm 0.67$ \\
\hline & Multimedia presentations (Prezi, PowerPoint) & $4.64 \pm 0.58$ & $4.55 \pm 0.61$ & $4.59 \pm 0.86$ & $4.57 \pm 0.72$ \\
\hline & Learning management system (LMS, Moodle, Blackboard) & $3.86 \pm 1.15$ & $3.86 \pm 1.02$ & $3.92 \pm 1.12$ & $4.02 \pm 0.99$ \\
\hline & Collaborative through Google+ & $3.71 \pm 0.97$ & $3.46 \pm 0.92$ & $3.65 \pm 0.82$ & $3.75 \pm 0.98$ \\
\hline & Virtual Tutorials (Zoom, Hangout) & $2.93 \pm 0.85$ & $2.71 \pm 0.77$ & $2.98 \pm 1.01$ & $3.02 \pm 0.44$ \\
\hline & Content platforms (WordPress, Blogger) & $2.52 \pm 1.10$ & $2.13 \pm 1.12$ & $2.84 \pm 1.15$ & $2.77 \pm 1.02$ \\
\hline & Educational forums for activities & $2.70 \pm 1.18$ & $2.42 \pm 1.15$ & $2.88 \pm 1.05$ & $2.90 \pm 1.30$ \\
\hline \multirow[t]{4}{*}{ Evaluate } & Rubrics through LMS & $3.33 \pm 1.18$ & $3.30 \pm 1.46$ & $3.08 \pm 1.53$ & $3.32 \pm 1.42$ \\
\hline & E-portfolios & $2.36 \pm 1.28$ & $2.47 \pm 1.44$ & $2.59 \pm 1.54$ & $2.57 \pm 1.49$ \\
\hline & LMS test controls & $3.48 \pm 0.98$ & $3.03 \pm 1.52$ & $3.00 \pm 1.50$ & $3.37 \pm 1.48$ \\
\hline & Forums to evaluate activities & $2.68 \pm 1.52$ & $2.75 \pm 3.03$ & $2.77 \pm 1.48$ & $2.93 \pm 1.52$ \\
\hline \multirow{7}{*}{ Research } & Search engines in databases (WoS, Dialnet, Theseus) & $4.29 \pm 0.93$ & $4.32 \pm 0.91$ & $4.01 \pm 1.17$ & $4.21 \pm 0.96$ \\
\hline & Search engines to consult (Google Scholar) & $4.52 \pm 0.80$ & $4.45 \pm 0.87$ & $4.28 \pm 1.06$ & $4.47 \pm 0.76$ \\
\hline & Making quotes (Refworks, Mendeley) & $3.65 \pm 1.34$ & $3.55 \pm 1.29$ & $3.08 \pm 1.55$ & $3.34 \pm 1.37$ \\
\hline & JCR and SJR magazine websites according to their quartiles & $4.42 \pm 0.96$ & $4.33 \pm 0.89$ & $3.50 \pm 1.43$ & $3.84 \pm 1.28$ \\
\hline & Social Networks (Research gate, Academy) & $3.83 \pm 1.28$ & $3.68 \pm 1.36$ & $3.85 \pm 1.40$ & $3.61 \pm 1.39$ \\
\hline & Researcher Profile (Researcher ID. ORCID) & $4.19 \pm 1.06$ & $3.84 \pm 1.23$ & $3.43 \pm 1.46$ & $3.62 \pm 1.37$ \\
\hline & Data analysis software (SPSS, Minitab, R) & $3.77 \pm 1.18$ & $3.84 \pm 1.23$ & $2.74 \pm 1.45$ & $3.43 \pm 1.35$ \\
\hline
\end{tabular}

Note: \pm means standard deviations

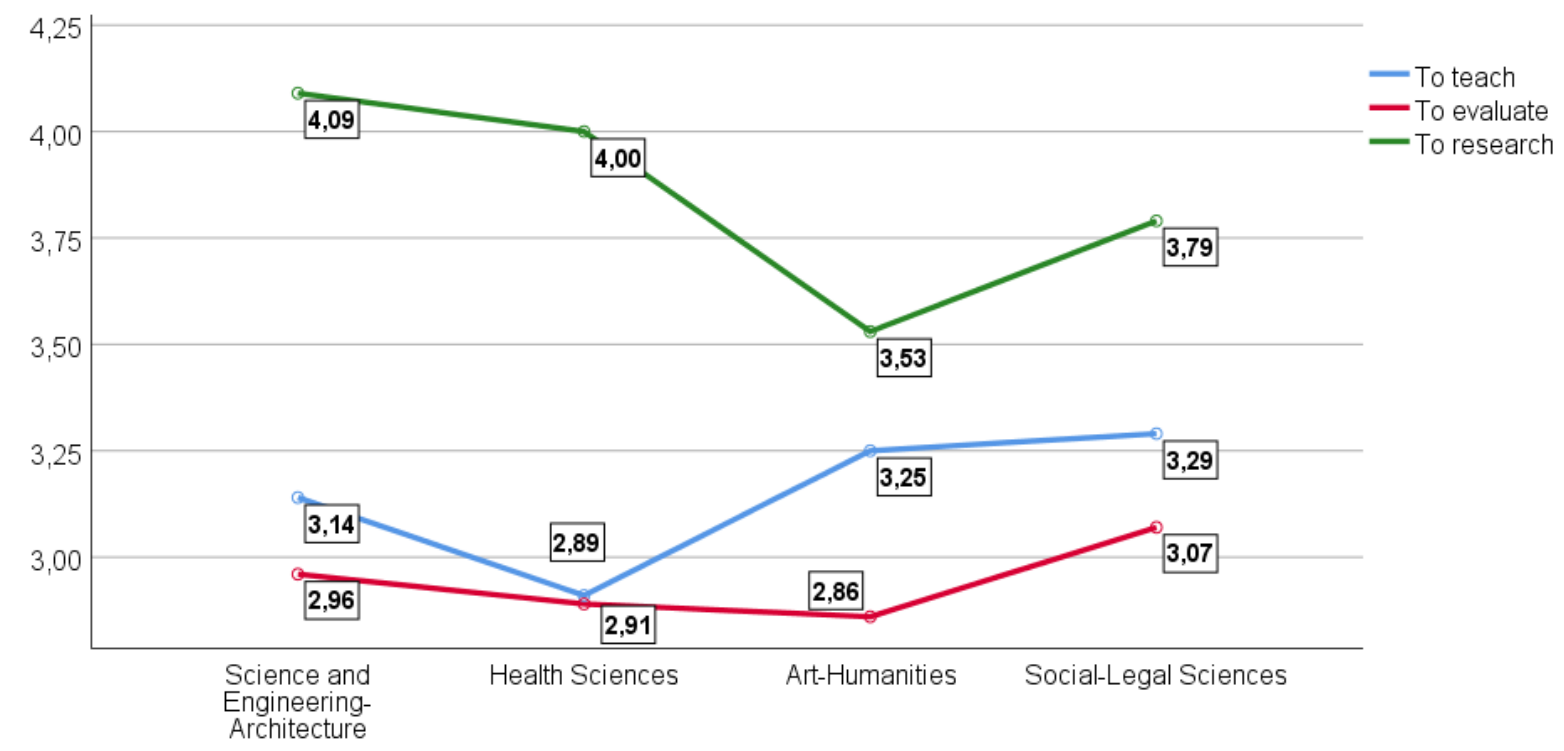

Figure 1. Total use of ICT resources in each dimension and in each area of knowledge

Figure 1 shows the total self-use perceived by teachers in each of the branches of knowledge, for each dimension. The use of ICT resources for Research purposes are the most employed ones in all areas, being higher in science and engineering-architecture $(M=4.09)$ and lower in art-humanities $(M=3.53)$. On the other hand, the ICT resources least used by teachers are those intended to evaluate, which obtained a similar general average in all areas, though slightly higher in social-legal sciences $(M=3.07)$. Digital teaching resources occupied a middling position, with less use in health sciences $(M=2.89)$.

\section{Analysis by Multiple Comparisons of the UTIC-EEI Model}

The analysis of variance (ANOVA) test was used to analyse the presence of statistical differences regarding the teachers' level of use according to the branch of knowledge to which they belong. For this purpose, the three dimensions of the UTIC-EEI instrument were used as dependent variables (DV): use of ICT resources to teach (DV 1), to evaluate (DV 2), to research (DV 3). The independent variable (IV) was the branch of 
Table 2. Levene and ANOVA tests

\begin{tabular}{lccccccc}
\hline Dimension & \multicolumn{3}{c}{ Levene's Equality Test } & \multicolumn{3}{c}{ ANOVA between subjects } \\
\cline { 2 - 8 } & $\mathrm{F}$ & $\mathrm{df1}$ & $\mathrm{df2}$ & Sig. & $\mathrm{F}$ & Sig. & Eta squared $\left(\mathrm{n}^{2}\right)$ \\
\hline Teach & 1.597 & 3 & 863 & 0.189 & 6.232 & 0.001 & 0.146 \\
Evaluate & 0.347 & 3 & 863 & 0.791 & 1.475 & 0.220 & 0.071 \\
Research & 9.515 & 3 & 863 & 0.001 & 11.809 & 0.001 & 0.199 \\
\hline
\end{tabular}

Table 3. Multiple comparisons between the branches of knowledge on the UTIC-EEI model

\begin{tabular}{llcccccc}
\hline Brach of knowledge Branch of knowledge & Teach & $\mathrm{d}$ & Evaluate & $\mathrm{d}$ & Research & $\mathrm{d}$ \\
\hline Health sciences & Science and engineering-architecture & 0.125 & - & 0.932 & - & 0.697 & - \\
& Art-humanities & $0.025^{*}$ & 0.332 & 0.997 & - & $0.001^{*}$ & 0.518 \\
& Social sciences & $0.001^{*}$ & 0.384 & 0.340 & - & $0.022^{*}$ & 0.253 \\
\hline Sciences and & Health sciences & 0.125 & - & 0.932 & - & 0.697 & - \\
engineering- & Art-humanities & 0.794 & - & 0.886 & - & $0.001^{*}$ & 0.617 \\
architecture & Social sciences & 0.326 & - & 0.756 & - & $0.001^{*}$ & 0.359 \\
\hline Art-humanities & Health sciences & $0.025^{*}$ & 0.332 & 0.997 & - & $0.001^{*}$ & 0.518 \\
& Science and engineering-architecture & 0.794 & - & 0.886 & - & $0.001^{*}$ & 0.617 \\
& Social sciences & 0.981 & - & 0.357 & - & 0.091 & - \\
\hline Social sciences & Health sciences & $0.001^{*}$ & 0.384 & 0.340 & - & $0.022^{*}$ & 0.253 \\
& Science and engineering-architecture & 0.326 & - & 0.756 & - & $0.001^{*}$ & 0.359 \\
& Art-humanities & 0.981 & - & 0.357 & - & 0.091 & - \\
\hline
\end{tabular}

* The difference in means is significant at the 0.05 level. $d=$ Cohen $d$ effect size

knowledge to which the teaching staff belong. Although Table 3 shows the results for each dimension of the instrument and for each branch of knowledge, for each comparison, a different ANOVA was used.

Regarding the assumption of data normality, the Kolmogorov-Smirnov test detected the absence of normality in each of the areas of knowledge ( $p .<0.05)$. However, Srivastava (1959) and Feir-Walsh and Toothaker (1974) state that non-normality does not have a serious effect in regard to the distribution of the data in the case of large samples. Taking into account the sample size of this study $(n=867)$, the $F$ statistic was strong for the post-hoc comparisons. In addition, the homoscedasticity in each of the instrument dimensions was verified using the Levene test (results shown in Table 2). For the teaching dimension, $F(3,868)=1,597 ;$ p. > 0.05 and the evaluation dimension, the $F(3,868)=.347$; p. $>0.05$ assumption was not violated, so multiple inter-subject comparisons were carried out using the Tukey test, while for the research dimension the homoscedasticity assumption was violated, $F(3,868)=9.515 ;$ p. $<0.05$, so comparisons were carried out using the Games-Howell method.

The results of the unifactorial ANOVA between groups indicated that there were statistically significant differences between the four knowledge branches and the mean scores in two of the instrument dimensions: the teaching dimension, with a small effect size, $F(3,863)=6,232, \mathrm{p} .<0.05, \mathrm{n}^{2}=0.146$; and the research dimension, with a medium-small effect, $F(3,863)=11.809$, p. $<0.05, \mathrm{n}^{2}=0.199$. According to Richardson (2011), eta square $\left(n^{2}\right)$ values of approximately $0.01,0.06$, and 0.14 indicate small, medium and large effects, respectively.

The analysis of the mean differences in the multiple comparisons by branch of knowledge carried out in regard to the use of ICT resources by teachers, indicated that in the teaching and research dimensions, the scores obtained differed. In the teaching dimension, there were significant differences between the teachers from the health sciences and art-humanities branches $\left(p_{.}=0.025\right)$, as well as between the health sciences and social sciences branches $(p .=0.001)$. In the research dimension, significant differences were evidenced between the health sciences and art-humanities branches $(p .=0.001)$, the health sciences and social sciences branches ( $\left.p_{.}=0.022\right)$, the sciences and engineering-architecture and art-humanities branches $(p .=0.001)$, and the sciences and engineering-architecture and social sciences branches $(p .=0.001)$. In those comparisons between the areas which have been significant, we have reported Cohen's $d$ for the difference between the means. Cohen suggested that $d=0.2$ be considered a 'small' effect size, 0.5 represents a 'medium' effect size and 0.8 a 'large' effect size. 


\section{DISCUSSION}

The objective of this work was to understand the didactic use made by Spanish university teachers in all branches of knowledge of different ICT resources, as well as to compare their use of these resources according to their specific branch of knowledge.

In relation to the first objective of this study, the results obtained showed a medium-high use of ICT resources in the four branches of knowledge considered. More specifically, a higher level of use in the teaching and research dimensions compared to the evaluation dimension was found in each branch of knowledge. Regarding the teaching dimension, the most-used resources in all branches were word processors and multimedia presentations, with the use of both resources being slightly higher in the science and engineeringarchitecture branch. These results are consistent with those obtained by Carrera and Coiduras (2012), Fernández-Márquez et al. (2018), and Pérez-Díaz (2019) which also found that, in the teaching dimension, the aforementioned resources were more commonly used than in the other dimensions, although in these studies they were more important in the social-legal sciences. University teachers made medium-high use of Google+ collaboration, with the usage being slightly higher in the social-legal sciences branch, and there was medium-high use of virtual learning platforms in all branches, though slightly higher use was recorded in the science and engineering-architecture branch. This is notable since, as Martínez and González (2015) indicate, Spanish teachers within this branch of knowledge are less aware of the potential of LMS to manage activities and resources. Content platforms or educational forums were less commonly used by teachers, with an average score in all branches of knowledge, and scores for both resources being slightly lower in the health sciences branch. These results on the didactic use of ICT resources agree with those reported by Prendes and Gutiérrez (2013) and De Ovando and Jara (2019) in respect to the health sciences branch. Furthermore, the results obtained are in line with those found by Carrera and Coiduras (2012) and Pérez-Díaz (2019) in regard to social and legal sciences, although, according to these studies, the teachers enrolled in the education sciences branch showed deficiencies in terms of their use of online editing tools or collaborative networking.

Regarding the evaluation dimension, according to the Spanish teachers surveyed, the most-used resources to assess students were the rubrics and test-type controls through EVA. Specifically, the use of rubrics was most common among the science and engineering-architecture and social-legal sciences teaching staff, while the test-type controls were more often used by teachers from the sciences and engineering-architecture branch. These results complement those obtained by Martínez and González (2015) since, according to their study, the use of spreadsheets to grade students was common. There was a medium level of use of eportfolios or forums to evaluate activities, being lower in the science and engineering-architecture branch.

When analysing the research dimension, significant variability between branches of knowledge regarding the use of ICT resources was evident. The most-used resources by Spanish teachers were web search engines: academic Google for scientific queries, followed by search engines in databases or impact journals, with the science and engineering-architecture branch obtaining a slightly higher average in relation to other branches of knowledge. This is particularly notable in the specific case of the social-legal sciences faculty, since Fernández et al. (2016) showed that business and economic teachers assigned great importance to the use of ICT to access information sources. This could be explained by the fact that there is a cognitive dissonance (Festinger, 1957) causing inconsistency between beliefs or attitudes and their behaviour. It is also noteworthy that teachers claimed to make medium-high use of programs for data analysis, with higher use in the health sciences branch compared to, for example, the art-humanities branch. This may be due to the type of research implemented, which stands out epidemiological research in health sciences, where very large samples will be needed, as well as further qualitative research for the arts-humanities branch. In summary, the findings obtained show that university teachers made appropriate use of ICT resources, regardless of the branch to which they are assigned.

In relation to the second aim of this research, focused on comparing the didactic use made by Spanish university professors of different ICT resources according to each branch of knowledge, the findings showed statistically significant differences between the four branches of knowledge in the teaching and research dimensions, and no differences in the evaluation dimension. Specifically, in the teaching dimension, the 
effect size was small among the different branches, although there were significant differences in the didactic use of ICT resources (for example, word processors or multimedia content) of the health sciences teachers compared with the art-humanities and social sciences teachers. In the research dimension, the differences found between the distinct branches determined a medium effect size, where the main variances were found between the health sciences and the art-humanities and social sciences branches, as well as between the sciences and engineering-architecture and the art-humanities and social sciences branches. In both dimensions the differences can be interpreted as coherent, since the science branches were differentiated on the one hand and the humanities on the other. In line with this, the differences found between the evaluation and research dimensions in the different branches of knowledge could be explained as being the result of teaching issues, since the methodological strategies used in the classrooms depended, to a large extent, on the content worked on (declarative/procedural/attitudinal) (Coll, Palacios, \& Marchesi, 2014), while in the case of research the strategies depended on the nature of the knowledge branch. For example, in health sciences, research concerns safety and efficacy in patient care (Cummings, Whetton, \& Mather, 2017); in this context, specific use will be made of databases, selection of journals, and software for data analysis.

At this point, the question remains as to why no significant differences were observed in the evaluation dimension since, if we follow the preceding argumentative thread, the content could be evaluated with ICT resources such as rubrics or test-type controls, regardless of the branch of knowledge.

\section{CONCLUSIONS}

The findings of this work have advanced the understanding of the didactic use of ICT resources, according to the UTIC-EEI model, by teachers across different branches of knowledge in the Spanish higher education system. It is essential that teachers from different branches of knowledge can teach the new profile of students (Montes \& Suárez, 2016), being familiar with the virtual world. In this way, they will not only contribute significantly to student learning, but also to training digital and critical citizens who can meet new professional requirements (Choi, Cristol, \& Gimbert, 2018) in the different branches of knowledge.

The results obtained have clear educational implications. The medium-high use of ICT resources indicates a change in the educational paradigm: ICT is significantly changing teaching across different branches of knowledge. It is possibly due to a greater use due to the incorporation of ICT resources in the classroom. However, teachers must provide a form of technology-mediated learning. For this, the universities of the $21^{\text {st }}$ century must guarantee that teachers can incorporate the use of these resources into their teaching practice according to quality pedagogical or didactic criteria. Thus, two kinds of training in the different branches of knowledge are necessary: on the one hand, to review the study plans of the different degrees so that ICT represents their related elements, so that university teachers can put into practice and develop in their students the digital skills necessary to train professionally competent digital citizens (Gleason \& Von Gillern, 2018); and on the other hand, to develop specific training plans for teachers in which they deepen their integration of technology in the classroom, to embrace the pedagogical possibilities offered by technology, to show educational applications in different contexts or examples of good practices with ICT (Prendes \& Gutiérrez, 2013), since it has been shown that technical training itself is not sufficient (Prendes \& Gutiérrez, 2013). Once the training plan is complete, its impact should be evaluated, as a common error, according to Pineda et al. (2014), is ignoring what happens and is implemented when training is complete. Despite this, it should not be forgotten that there are difficulties in transferring training to teaching practice (Cejas-León \& Navío-Gámez, 2018).

Finally, it would be interesting to consider other variables in order to delve deeper and obtain a broader perspective of the obtained results. For example, recent studies (Fernández-Cruz \& Fernández-Díaz, 2016) have shown that age is inversely proportional to the use of ICT resources. In future research, it could be verified whether this trend has continued or if the incorporation of young university teaching staff in the educational system is reducing this digital gap. In addition, it would be interesting to be able to continue this study in each area of knowledge (social sciences, human sciences, architecture, engineering, art (among 
others ...), with the purpose of knowing the use of ICT resources in each area, and of in this way, focus the development of the digital competence of teachers specifically.

\section{REFERENCES}

Adetimirin, A. (2019). Female Lecturers' Perception of ICT Integration for Teaching and Learning in University of Ibadan, Nigeria. In Gender and Diversity: Concepts, Methodologies, Tools, and Applications (pp. 1624-1636). IGI Global. https://doi.org/10.4018/978-1-5225-6912-1.ch084

Arancibia, M., Valdivia, I., Araneda, S., \& Cabero, J. (2017). Tipologías para la Innovación tecnológica en Docentes de Educación Superior a partir de un análisis de conglomerados: un estudio exploratorio. RED. Revista de Educación a Distancia, 55, 1-21. https://doi.org/10.6018/red/55/5

Bentler, P. M. (1989). EQS structural equations program manual. Los Angeles: BMDP Statistical Software.

Bingimlas, K. A. (2009). Barriers to the successful integration of ICT in teaching and learning environments: A review of the literature. Eurasia journal of mathematics, science \& technology education, 5(3), 235245. https://doi.org/10.12973/ejmste/75275

Blackwell, B. (1992). Sick-role susceptibility. Psychotherapy and Psychosomatics, 58(2), 79-90. https://doi.org/10.1159/000288614

Capilla, M. M., Torres, J. M. T., \& Sánchez, F. R. (2016). Percepción del profesorado y alumnado universitario ante las posibilidades que ofrecen las TIC en su integración en el proceso educativo: reflexiones, experiencias e investigación en la Facultad de educación de Granada. EDMETIC, 5(1), 113-142. https://doi.org/10.21071/edmetic.v5i1.4019

Carrera, X., \& Coiduras Rodríguez, J. L. (2012). Identificación de la competencia digital del profesor universitario: un estudio exploratorio en el ámbito de las Ciencias Sociales. Red-U: Revista de docencia universitaria, 10(2), 273-298. https://doi.org/10.4995/redu.2012.6108

Carvalho, I. S. G., Tejada, J., \& Pérez, K. V. P. (2019). Formación docente para la educación a distancia: la construcción de las competencias docentes digitales. Série-Estudos-Periódico do Programa de PósGraduação em Educação da UCDB, 24(51), 69-87. https://doi.org/10.20435/serie-estudos.v24i51.1296

Cejas-León, R., \& Navío Gámez, A. (2018). Formación en TIC del profesorado universitario. Factores que influyen en la transferencia a la función docente. Profesorado. Revista de Currículum y Formación de Profesorado, 22(3), 271-293. https://doi.org/10.30827/profesorado.v22i3.8002

Cela-Ranilla, J. M., González, V. E., Mon, F. E., Martínez, J. G., \& Gisbert-Cervera, M. (2017). El docente en la sociedad digital: una propuesta basada en la pedagogía transformativa y en la tecnología avanzada. Profesorado. Revista de Currículum y Formación de Profesorado, 21(1), 403-422.

Choi, M., Cristol, D., \& Gimbert, B. (2018). Teachers as digital citizens: The influence of individual backgrounds, internet use and psychological characteristics on teachers' levels of digital citizenship. Computers \& Education, 121, 143-161. https://doi.org/10.1016/j.compedu.2018.03.005

Colas-Bravo, M.P., De Pablos-Pons, J., \& Ballesta-Pagan, J. (2018). Incidencia de las TIC en la enseñanza en el sistema educativo: una revisión de la investigación. Revista de Educación a Distancia, 56, 1-23. https://doi.org710.6018/red/56/2

Coll, C., Palacios, J., \& Marchesi, A. (2014). Desarrollo psicológico y educación. 2. Psicología de la educación escolar. Alianza.

Cummings, E., Whetton, S., \& Mather, C. (2017). Integrating Health Informatics Into Australian Higher Education Health Profession Curricula. A. Shachak, E.M. Borycki, \& S. P. Reis, (ed.) Health Professionals' Education in the Age of Clinical Information Systems, Mobile Computing and Social Networks (pp. 323343). Londres: Academic Press. https://doi.org/10.1016/B978-0-12-805362-1.00016-4 
De Ovando, J. S., \& Jara, V. J. (2019). Competencia digital de docentes de Ciencias de la Salud de una universidad chilena. Píxel-Bit. Revista de Medios y Educación, 56, 193-211. https://doi.org/10.12795/pixelbit.2019.i56.10

Díaz, V. M., Hernández, M. R., \& Berea, G. A. M. (2016). Valoraciones del profesorado universitario sobre la integración de las TIC en el aula. EDMETIC, 5(1), 177-200. https://doi.org/10.21071/edmetic.v5i1.4022

DiVall, M. V., Hayney, M. S., Marsh, W., Neville, M. W., O’Barr, S., Sheets, E. D., \& Calhoun, L. D. (2013). Perceptions of pharmacy students, faculty members, and administrators on the use of technology in the classroom. American Journal of Pharmaceutical Education, 77(4), 75. https://doi.org/10.5688/ajpe77475

Dzikite, C., Nsubuga, Y., \& Nkonki, V. (2017). Lecturers' Competencies in Information and Communication Technology (ICT) for Effective Implementation of ICT-Integrated Teaching and Learning in Textiles and Clothing Degree Programmes. International Journal of Educational Sciences, 17(1-3), 61-68. https://doi.org/10.1080/09751122.2017.1305756

European Comission (2012). Communication from the commission to the european parliament, the council, the european economic and social committee and the committee of the regions. COM/2018/029 final. Strasbourg. Retrieved from https://eur-lex.europa.eu/legal-content/BG/TXT/PDF/?uri=CELEX: 52018DC0029\&from=ES

Feir-Walsh, B. J., \& Toothaker, L. E. (1974). An empirical comparison of the ANOVA F-test, normal scores test and Kruskal-Wallis test under violation of assumptions. Educational and Psychological Measurement, 34(4), 789-799. https://doi.org/10.1177/001316447403400406

Fernández, M. R., Sánchez-Oro, M., \& Robina, R. (2016). La evaluación de la competencia digital en la docencia universitaria: el caso de los grados de empresariales y económicas. Revista Colombiana de Ciencias Sociales, 7(2), 332-348. https://doi.org/10.21501/22161201.1726

Fernández-Cruz, F., \& Fernández-Díaz, M. J. (2016). Los docentes de la Generación Z y sus competencias digitales. Comunicar, 46, 97-105. https://doi.org/10.3916/C46-2016-10

Fernández-Márquez, E., Leiva-Olivencia, J. J., \& López-Meneses, E. (2018). Competencias digitales en docentes de Educación Superior. Revista Digital de Investigación en Docencia Universitaria, 12(1), 213231. https://doi.org/10.19083/ridu.12.558

Festinger, L. (1957). A theory of cognitive dissonance. Stanford University Press.

From, J. (2017). Pedagogical Digital literacy--Between Values, Knowledge and Skills. Higher Education Studies, 7(2), 43-50. http://doi.org/10.5539/hes.v7n2p43

Gleason, B., \& Von Gillern, S. (2018). Digital citizenship with social media: Participatory practices of teaching and learning in secondary education. Journal of Educational Technology \& Society, 21(1), 200-212.

Gorghiu, G., Gorghiu, L. M., \& Pascale, L. (2018). Enriching the ICT competences of university students-a key factor for their success as future teachers. Journal of Science and Arts, 18(1), 183-190.

Guillén-Gámez, F. D., \& Mayorga-Fernández, M. J. (2019). Prediction and explanation of factors that affect the digital literacy of lecturers. A case study of Spanish University. Journal of learning in higher education, 26(2), 107-117. https://doi.org/10.18848/2327-7955/CGP/v26i02/107-117

Guillén-Gámez, F. D., Mayorga-Fernández, M. J., \& Del Moral, M. T. (2020a). Comparative research in the digital competence of the pre-service education teacher: face-to-face vs blended education and gender. Journal of e-Learning and Knowledge Society, 16(3), 1-9. 
Guillén-Gámez, F. D., Mayorga-Fernández, M. J., Bravo-Agapito, J., \& Escribano-Ortiz, D. (2020b). Analysis of Teachers' Pedagogical Digital literacy: Identification of Factors Predicting Their Acquisition. Technology, Knowledge and Learning, 1-18. https://doi.org/10.1007/s10758-019-09432-7

Gutiérrez, S. S. M., Torres, N. J., \& Sánchez-Beato, E. J. (2016). La evaluación del alumnado universitario en el Espacio Europeo de Educación Superior. Aula Abierta, 44(1), 7-14. https://doi.org/10.1016/j.aula.2015.03.003

Hatlevik, O. E., \& Christophersen, K. A. (2013). Digital literacy at the beginning of upper secondary school: Identifying factors explaining digital inclusion. Computers \& Education, 63, 240-247. https://doi.org/10.1016/j.compedu.2012.11.015

Hernández, R. M. (2017). Impacto de las TIC en la educación: Retos y Perspectivas. Propósitos y representaciones, 5(1), 325-347. https://doi.org/10.20511/pyr2017.v5n1.149

Hu, L. T., \& Bentler, P. M. (1999). Cutoff criteria for fit indexes in covariance structure analysis: Conventional criteria versus new alternatives. Structural equation modeling: a multidisciplinary journal, 6(1), 1-55. https://doi.org/10.1080/10705519909540118

Janssen, J., Stoyanov, S., Ferrari, A., Punie, Y., Pannekeet, K., \& Sloep, P. (2013). Experts' views on digital literacy: Commonalities and differences. Computers \& Education, 68, 473-481. https://doi.org/10.1016/j.compedu.2013.06.008

Karpudewan, M., \& Balasundram, N. (2019). Addressing Alternative Conceptions about Transition Metals among Form Six Students using Information and Communication Technology based Instruction. Eurasia Journal of Mathematics, Science and Technology Education, 15(7), em1731. https://doi.org/10.29333/ejmste/103356

Kerlinger, F. N., Lee, H. B., Pineda, L. E., \& Mora Magaña, I. (2002). Investigación del comportamiento. México City: McGraw Hill.

Ladrón-de-Guevara, L., Almagro, B. J., \& Cabero, J. (2019). El conocimiento tecnológico, pedagógico y disciplinar del profesorado universitario de Educación Física. Retos: nuevas tendencias en educación física, deporte y recreación, 36, 362-369.

Lai, Y.-H. (2019). A Network Meta-Analysis on the Effects of Information and Communication Technology on Students' Learning Achievement in Taiwan. Eurasia Journal of Mathematics, Science and Technology Education, 15(3), em1675. https://doi.org/10.29333/ejmste/102846

Llorente, M. D. C. (2008). Aspectos fundamentales de la formación del profesorado en TIC. Pixel-Bit, 31, 121130.

López, B. A. A., Sánchez, R. L., Arámbula, R. E., \& Esquivel, A. L. E. (2019). El profesorado Universitario en el uso e impacto de la Tecnología Educativa. KIKAME, 5(5), 61-67.

Lorenzo, J. (2018). Uso de TIC en docentes de nivel medio, terciario y universitario de ciencias humanas y sociales. La escuela de hoy. Tensiones, posibilidades y desafíos, 1, 89-104.

Martínez, F., \& González, J. (2015). Uso y apropiación de las Tecnologías de la Información y la Comunicación por parte de los docentes en las facultades de ingeniería. Redes de Ingeniería, 6(1), 6-24. https://doi.org/10.14483/udistrital.jour.redes.2015.1.a01

Mercader, C. (2019). Las resistencias del profesorado universitario a la utilización de las tecnologías digitales. Aula Abierta, 48(2), 167-174. https://doi.org/10.17811/rifie.48.2.2019.167-174

Ministerio de Educación, C. y D. (MECD, 2019). Datos y cifras del sistema universitario español. Retrieved from http://www.educacionyfp.gob.es/dam/jcr:2af709c9-9532-414e-9bad-c390d32998d4/datos-ycifras-sue-2018-19.pdf 
Montes, D., \& Suárez, C. (2016). La formación docente universitaria: claves formativas de universidades españolas. Revista Electrónica de Investigación Educativa, 18(3), 51-64. Retrieved from http://redie.uabc.mx/redie/article/view/996

Nafría, I. (2007). Web 2.0: El usuario, el nuevo rey de Internet. Barcelona: Gestión 2000.

Ojeniyi, A. O., \& Adetimirin, A. E. (2016). ICT literacy skills and electronic information resources use by lecturers in two private universities in Oyo State, Nigeria. Library Philosophy and Practice (e-journal), 1-19. Retrieved from http://digitalcommons.unl.edu/libphilprac/1443

Padilla-Hernández, A. L., \& Vanesa, M. (2018). Selección de categorías para el estudio de la evolución de la competencia digital docente del profesorado en Educación Superior. Revista Interuniversitaria de Investigación en Tecnología Educativa, 4, 55-67. https://doi.org/10.6018/riite/2018/327881

Pérez-Díaz, R. (2019). Competencia Digital Docente en los Institutos Superiores de Formación de Maestros: Caso de República Dominicana. Pixel-Bit. Revista de Medios y Educación, 55, 75-97. https://doi.org/10.12795/pixelbit.2019.i55.05

Pineda, P. (2010). Evaluation of training in organisations: a proposal for an integrated model. Journal of European Industrial Training, 34(7), 673-693. https://doi.org/10.1108/03090591011070789

Pozos, K. (2016). Evaluación de necesidades de formación continua en competencia digital del profesorado universitario mexicano para la sociedad del conocimiento. Tesis (Doctorado en Calidad y Procesos de Innovación Educativa) - Universitat Autònoma de Barcelona (UAB), Bellaterra, España, 2015.

Prendes, M., \& Castañeda, L. (2010). Universidades Latinoamericanas ante el reto de las TIC: Demandas de Alfabetización tecnológica para la docencia. In Congreso Euro-lberoamericano de Alfabetización Mediática y Culturas Digitales (2010). Universidad de Sevilla.

Prendes, M., \& Gutiérrez, I. (2013). Competencias tecnológicas del profesorado en las Universidades Españolas. Revista de Educación, 361, 1-16. https://doi.org/10.4438/1988-592X-RE-2011-361-140

Prendes, M., Gutiérrez, I., \& Martínez, F. (2018). Competencia digital: una necesidad del profesorado universitario en el siglo XXI. RED: Revista de Educación a Distancia, 56(7), 1-22. https://doi.org/10.6018/red/56/7

Richardson, J. (2011). Eta Squared and Partial Eta Squared as Measures of Effect Size in_Educational Research. Educational Research Review, 6(2), 135-147. https://doi.org/10.1016/j.edurev.2010.12.001

Ríos, J. M., Gómez, E., \& Rojas, M. P. (2018). Valoración de competencias TIC del profesorado universitario: un caso en Chile. Pixel-BIT. Revista de Medios y Educación, 52, 55-65. https://doi.org/10.12795/pixelbit.2018.i52.04

Rivera-Laylle, L. I., Fernández-Morales, K., Guzmán-Games, F. J. \& Eduardo-Pulido, J. (2017). ICT Acceptance by University Professors: Knowledge, Attitude, and Practicality. Revista Electrónica Educare, 21(3), 99116. https://doi.org/10.15359/ree.21-3.6

Sahin, I., \& Thompson, A. (2006). Using Rogers' theory to interpret instructional computer use by COE faculty. Journal of Research on Technology in Education, 39(1), 81-104. https://doi.org/10.1080/15391523.2006.10782474

Srivastava, A. B. L. (1959). Effect of non-normality on the power of the analysis of variance test. Biometrika, 46(1/2), 114-122. https://doi.org/10.2307/2332813

Correspondence: Francisco David Guillén-Gámez, Department of Research and Diagnostic Methods in Education, Faculty of Education, University of Zaragoza (UNIZAR), Spain. E-mail: dguillen@unizar.es 